\title{
Overview of Foreign Labour Migration in Nepal
}

\begin{abstract}
Migration is a major area of population and development. This study identifies the trend and destination of foreign labor migration in Nepal. Nepal's economy is associated with the increase in foreign employment trends. Although recent trends have shown continuous increase in the pattern, there is much uncertainty on how long the trend can sustain or at what levels. Studies suggest that the demand for labour migrants in GCC (Gulf Cooperative Council) countries and Malaysia will continue in the near future, although multiple factors (not just the demand in the international market) influence any one worker's decision to opt for foreign employment. The overall increasing number of labour permits issued is only one aspect of the foreign employment trend. Understanding associated trends is also necessary from a national development point of view: foreign employment and national development. There is need for a more comprehensive understanding of how the benefits of foreign employment can be optimized for use in national development beyond 2019.
\end{abstract}

Key Words: Labour migration, Remittance, Impact, Household and policies.

\section{Introduction}

Labour migration is defined as the movement of persons from their home State to another State for the purpose of employment. Today, an estimated 86 million persons are working in a country other than their country of birth. Despite the efforts made to ensure the protection of migrant workers, many migrants continue to experience numerous problems particularly more vulnerable groups, such as female domestic workers, entertainers and lower skilled workers (UN, 2019).Scholars do not take uniform approach regarding migration to and from Nepal. The arrival from the north of people speaking Tibeto-Burman languages between the 5 th and 10th centuries, and of Indo-Aryan groups, especially Brahmins and Kshatriyas, from the south from the 9th to the 13th centuries to what is present-day (Adhikary\&Gurung, 2009). Nepal's links were equally strong with both the north and the south. Most parts of Nepal had greater economic ties and closer cultural affinity with Tibet until the early 19th century than with any other country. There were more Nepalese in Tibet than anywhere else outside Nepal, and more people of Tibetan origin than of Indian origin were known to be living in Nepal at that time (Bisth, 1980). The history of formal foreign labor migration begins in 1814-1816, after the Anglo-Nepal war. A total of 4,650 Nepalese youngsters were 
recruited to the British armed forces in the British-Gurkha regiment after the conclusion of the war and signing of the Treaty of Sugauli in 1816 (ILO-DFID, 2002).

The 1950 Nepal-India Treaty of Peace and Friendship formalized the free movement of people between the two countries without requirements of any formalities like passports and visas. During the 19th and 20th centuries, the Nepalese migrant population dispersed to other countries as well, namely, Bhutan, Burma, Malaysia (then Malaya), Thailand, Bangladesh (then part of India) and Tibet. While Nepalese emigrants to Tibet were essentially traders, migration to Malaysia is associated with Nepalese working in plantations growing rubber, sugar and palm, and in Thailand Nepalese worked at important market places in Bangkok (Kansakar, 2005). As reported in the Nepal Living Standards Survey (NLSS) 2010/11, 53 per cent of households in Nepal have at least one absentee living within or outside the country. According to the census data, between 2001 and 2011, there was more than a two-fold increase in the number of Nepalese living away from the country (Table, 1). The implication of this trend is significant. The average annual growth rate of Nepal's absentee population between 2001 and 2011 was 9.2 per cent (CBS, 2014).

Foreign employment is indeed the most significant motivation for international migration from Nepal in the twenty-first century. In today's increasingly interconnected world, international migration has become a reality that touches nearly all corners of the globe. Modern transportation has made it easier, cheaper and faster for people to move in search of jobs, opportunity, education and quality of life. At the same time conflict, poverty, inequality and a lack of sustainable livelihoods compel people to leave their homes to seek a better future for themselves and their families abroad. The numbers of international migrants worldwide have continued to grow rapidly in recent years, reaching 258 million in 2017, up from 220 million in 2010 and 173 million in 2000. Over 60 per cent of all international migrants live in Asia 80 million or Europe 78 million. Northern America hosted the third largest number of international migrants 58 million, followed by Africa 25 million, Latin America and the Caribbean 10 million and Oceania 8 million (United Nations, 2017).With the global rise in migration of workers across countries, attention to the economic and social well-being of migrants, their families and their communities has been increasing.

The number of international migrants in the world today is unprecedented. The International Migration Report 201743 and the Global Report on Internal Displacement (GRID) 201944 cover the latest global migration and displacement trends including the following highlights. High income countries hosted 64 per cent or nearly 165 million of the total number of international migrants worldwide which is estimated at 258 million. In 2017, 48.8 per cent of all international migrants were women. In nearly all regions except Africa and Asia female migrants 
outnumber males. Insome countries in Asia however the number of male migrants to female migrants is about three to one.

More than 80 million international migrants reside in Asia, a number that has grown by 30 million since 2000. In 2017, Asia was the region of origin for 106 million migrants. Between 2000 and 2017, the relative increase in the number of international migrants who had originated in Asia and stayed in Asia was 62 percent.

More than 3.8 million permits to work abroad (excluding India) were issued by the Government during the 1993/94-2014/15 fiscal years, which represents almost 14 per cent of the current population. As well, according to the recent census data (2011), nearly 71 per cent of the total absent population $(1,921,494)$, or people living out of the country (including living in India) cited private and institutional jobs abroad as the reasons for leaving. Subsequently, there has been a huge increase in the inflow of remittances, from 58.6 billion rupees (NPR) in 2003/04 to NPR589.5 billion in 2014/15. Remittances contributed a 10.9 percentage share of the gross domestic product (GDP) in 2003/04 and 27.7 per cent in 2014/15. Migration trend shows that Middle East countries like Malaysia, Qatar, UAE and Saudi Arabia have been attractive destinations for Nepalese workers (MoLE, 2016).

Movement of population across the international borders of Nepal has two components. The first is emigration, or the Nepal born population reported as absentees abroad, and second, immigration or the foreign-born population reported within Nepal. This paper is limited only to the emigration. As the number of labor migrants every year increases, there is increasing share of international migrant workers of Nepal. Nepali migrant workers continue to fill the labor gaps especially in Gulf Cooperation Council (GCC) countries and Malaysia. Nepal is the third-highest recipient of remittances as a share of GDP, among all countries and ranks first among the SAARC countries (WB, 2019).

The remittance flow, therefore, is a major contributor to development financing in Nepal. The outflow of migrants in the past decade has been momentous in transforming the country's economic, social and cultural fabric. Nepal has emerged as a remittance economy, shaped by migrants' cash flows, so much so that it was the third-largest recipient of remittances - as a share of GDP - in the world in 2012 and the top recipient among least developed countries. Foreign employment has provided alternative livelihood opportunities, and remittances have helped to augment household incomes. Among the many impacts of foreign employment, the social dynamics have changed, with many people in the workingage population, particularly men, absent from home. Additionally, cultural norms are being transformed as more women join the labour force nationally and internationally. The voluminous nature of labour migration for employment has brought both new opportunities and challenges for the Government and policy-makers. A primary concern has been in 
managing the huge outflow while ensuring the safety, rights, decency and welfare of migrant workers. This has required strengthening the governance process, creating cohesive legislation and policies and ensuring their proper implementation. Despite the legislation and policies and an increase in migrant workers opting to go abroad via regular channels, there are still gaps in the implementation of such legislation and policies. These gaps have hampered the rights and safety of migrants. The cases of labour migrants suffering from abuses, exploitation and financial distress are frequent and impinge on their rights and wellbeing. Emphasis on strategies for safe and better remunerative labour migration oriented around labour and human rights and a much deeper and more comprehensive understanding of the foreign employment phenomenon in all of its dimensions, such that it may be harnessed for national development, are needed in the current context. Thus, the aim of this report is to document the current data, trends, issues and challenges relating to foreign employment and inform various country-level initiatives in both sending and receiving countries, including policy decisions and the improvement of migration management mechanisms and governance institutions to promote safe and dignified migration.

\section{Objectives}

- This study is to identify the trend and destination of foreign labor migration in Nepal.

- To find out the highlight government-led initiatives at the policy and structural levels that promotes safe migration and protects the rights and welfare of migrant workers.

\section{Methodology}

This article developed by the secondary sources through the International Labour Organization, the International Organization for Migration and The Asia Foundation. The author used same data sources in the previous reports, which were mainly the Department of Foreign Employment, the Foreign Employment Promotion Board. The trends in foreign employment are presented for past eight years, 2009/10-2016/17. Although the first report covered trends and data until 2018/19, this report reiterates those trends along with updated data from the past fiscal year to create a single comprehensive report for readers' easy reference.

\section{Limitations}

This article is limited to the official data available at the different levels of government institutions. By using the data for the past eight years, the report only presents current trends. The use of labour permits issued by the Department of Foreign Employment as the primary indicator limits the assessment to the nature, scale and magnitude of labour migrants in foreign employment. A few technical considerations were required in presenting 
the overview data on labour migration. The Department of Foreign Employment database is online and provides real-time data used.

\section{Resultsand Discussion}

\section{Trends of Labor Migration}

The government of Nepal formally allows Nepali nationals to go and work in 110 countries. However, majority of migrants are concentrated in the Gulf Cooperation Council countries (Bahrain, Kuwait, Oman, Qatar, Saudi Arabia, and the United Arab Emirates) and Malaysia. The lack of employment opportunities in Nepal is considered to be the major push factor for the increased volume of labor migration.

The Department of Foreign Employment (DoFE) under the Ministry of Labor regularly updates the number of people going abroad by taking individual and institutional permission. A total of 3,289,668 labor permits were issued by the Department of Labor and Employment from 2009/10 through 2016/17. The surge in the outflow of labour migrants in recent years, especially to Gulf Cooperation Council (GCC) countries and to Malaysia, appears frequently in migration analyses. This section and accompanying annexes provide information on labour migration out of Nepal, based on data for 2008/09 to 2014/15.A total of 2,723,587 labour permits were issued by the Department of Labour and Employment from 2008/09 through 2014/15.As illustrated in Figure 1, there was a steady increase in issued permits until 2013/14, when the total number dipped slightly. The 3.8 per cent decrease in 2014/15 from the previous year is attributed to the earthquake that hit Nepal in April 2015. The earthquake and subsequent aftershocks, which occurred in the last quarter of the fiscal year, disrupted all aspects of everyday life, including the operation of both government and private institutions facilitating foreign employment.

Table 1: Trends of labor migrants going abroad by taking official permission, 2009/10- 2016/17

\begin{tabular}{|l|l|l|l|}
\hline Sn.no & Fiscal year & $\begin{array}{l}\text { Rate of increase in absolute } \\
\text { terms (\% male) }\end{array}$ & $\begin{array}{l}\text { Rate of increase in absolute terms } \\
\text { (\% female) }\end{array}$ \\
\hline 1 & $2009 / 10$ & 96.6 & 3.4 \\
\hline 2 & $2010 / 11$ & 97.1 & 2.9 \\
\hline 3 & $2011 / 12$ & 94 & 6 \\
\hline 4 & $2012 / 13$ & 93.85 & 6.15 \\
\hline 5 & $2013 / 14$ & 94.4 & 5.6 \\
\hline 7 & $2014 / 15$ & 95.71 & 4.29 \\
\hline 8 & $2015 / 16$ & 95.42 & 4.58 \\
\hline 9 & $2016 / 17$ & 94.74 & 5.26 \\
\hline
\end{tabular}

Sources: Nepal international migration survey, 2016/17.

Figure No.1: Trends of labor migrants going abroad by taking official permission, 2009/10- 
2016/17

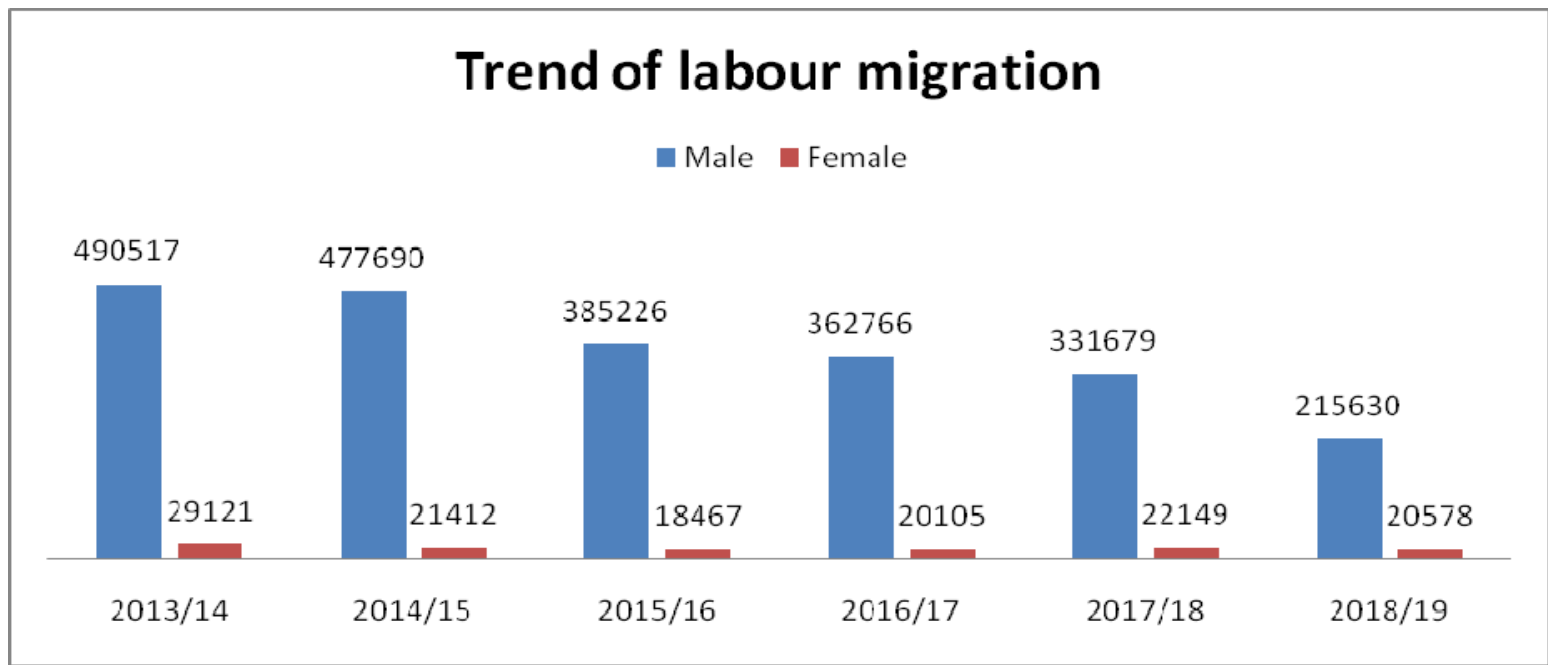

Source: UN, 2019

Figure 1 shows that there has been steady increase in issued permits between 2009/10 to $2013 / 14$, but the numbers have declined from 2014/15 to 2016/17. The total number of workers migrating abroad has been increasing continuously. There are two responsible factors for such a growing trend of Nepalese workers going abroad for employment. These factors are pull factors and push factors. High demand of labor in industrialized and developed nations like East Asian nations, Middle East nations and Gulf nations are main pull factors. Dearth of employment opportunity in the nation, distorted peace and security, low wage level, lack of agricultural development in rural areas, scarcity of basic services needed for survival, liberal policies of government and demonstration effect are main push factors. International migration and paid-employment are male-dominated phenomena in Nepal.

\section{Destination countries of labour migrants}

Nepali labour migrants have obtained permits to work in as many as 142 countries over the past seven fiscal years (2008/09-2014/15). Any country that is a member of the United Nations, unless banned by the Government of Nepal, may be chosen by a migrant worker as destination country, although the Government limits the number of countries that may be managed for employment through recruitment agencies. Malaysia and the GCC countries have been the most attractive destinations, receiving 85 per cent of all male and female labour migrants in the past seven fiscal years. As shown in Figure 3, of the total 2,723,587 labour permits issued over that period, 33.3 per cent were for employment in Malaysia, followed by Qatar (at 19 per cent), Saudi Arabia (18.9 per cent), United Arab Emirates (9.8 
percent), Kuwait (2.5 per cent), Bahrain (0.9 per cent) and Oman (0.6 per cent).Although there are comparatively small numbers of migrants going to the Republic of Korea, it has emerged as a favorable destination country in the past seven years largely because of the government to-government agreement that enables good wages and good living and working conditions. Of the 35,585 labour permits issued between 2008/09 and 2014/15 for the Republic of Korea, 95.4 per cent were arranged through the EPS scheme. Among the remaining popular countries and territories, Afghanistan, Japan, Jordan, Lebanon and Macau (China) have remained popular destinations while new destinations have emerged: Mauritius, Democratic Republic of Congo, Seychelles and Uzbekistan. As shown in Figure 4, there has been a huge surge in migrants obtaining labour permits for Malaysia, with a nearly 600 per cent increase between 2008/09 and 2013/14. Such a meteoric increase has also occurred in four other countries: Kuwait, Qatar, Saudi Arabia and the United Arab Emirates.

\section{Destination of Nepalese Migrants}

The Department of Foreign Employment data indicate that Nepalese labor migrantsobtained a labor permit for employment in 153 destination countries. Malaysia, Qatar, Saudi Arabia, United Arab Emirates, Kuwait, had have the larger numbers of permits grantedof the total migration.

Figure No. 2: Destination country of Nepali foreign labour migrants.

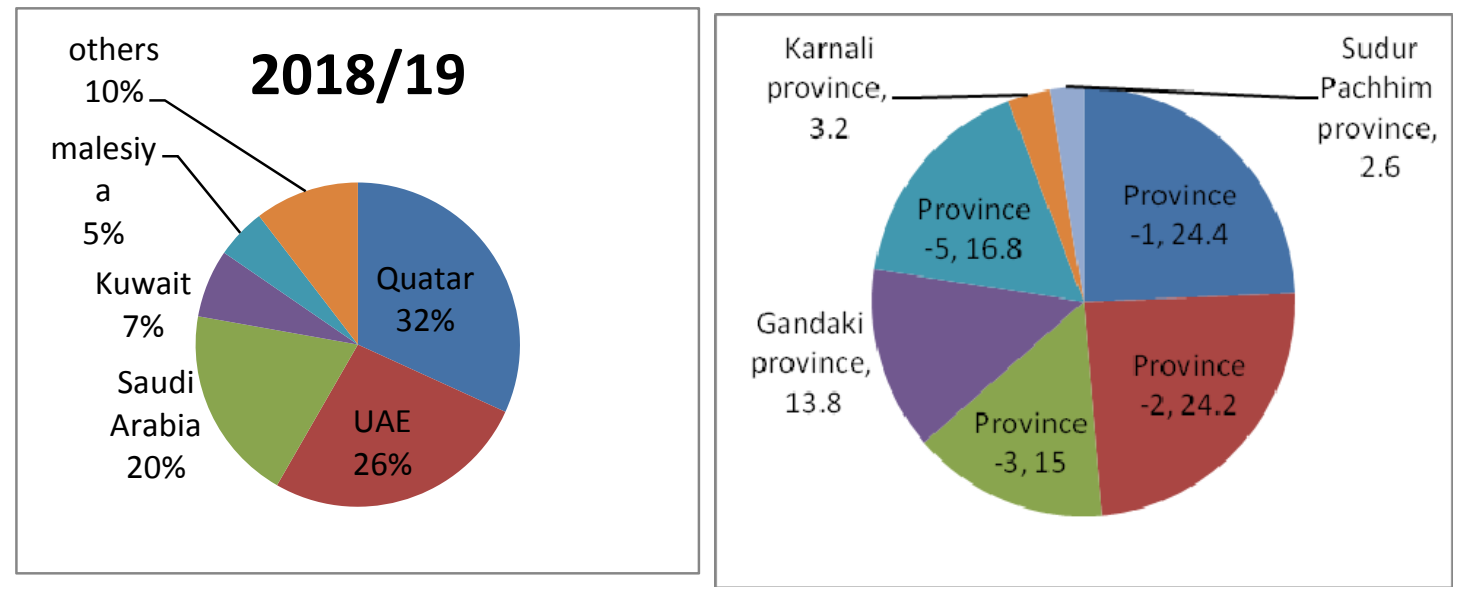

Foreign labour Migration by Province, 2018/19, Migration in Nepal: A Country Profile 2019

Malaysia is the first attractive destination for Nepali labor migrants. Till mid-March of FY 2018/19, out of total number of workers migrated for foreignemployment, 30.1 percent workers have been migrated to Malaysia, 27.4 percent toQatar, 20.2 percent to Saudi Arabia, 13.1 percent to United Arab Emirates and 9.2 percentto other countries. 


\section{Impact of Remittances on Nepali Households (HHs)}

When comparing the structure of Nepali HH budgets between remittance-receiving and nonreceiving $\mathrm{HHs}$, it is clear that remittances have a significant positive impact on the overall $\mathrm{HH}$ budget (Figure 50), representing the main income source for their household budget. This is valid for both HHs with long-term and short-term migrant workers. Remittances contribute 62 per cent to the budgets of remittance-receiving HHs with long-term migrant workers and 38 per cent to the budgets of remittance-receiving HHs with short-term migrant workers. Even in the case of remittance-receiving HHs without migrant workers, the impact of remittances is a significant $22 \%$ of their overall budgets, having the same weight as incomes gained from the private sector (23\%) and loans (19\%).In the case of HHs not receiving remittances, the main income sources have a larger variety from one to another $\mathrm{HH}$ category: non-receiving HHs with short-term migrant workers rely mainly on sales from internal products (24\%), non-agricultural seasonal activity (24\%), loans (16\%), and other business (13\%) non-receiving HHs with long-term migrant workers rely mainly on loans (28\%), sales from internal products (16\%), and other business (14\%)non-receiving HHs without migrant workers rely mainly on other business activities (24\%), salary from private sector (16\%) and public sector (11\%), but also loans (14\%) and sales from internal products (12\%)Of particular interest in the case of Nepal compared to SEEE countries studied is the insignificant contribution of salaries from private and public sectors to the Household (HH) budget, especially in the case of HHs with migrant workers, as well as the heavy reliance on loans, excluding remittance-receiving HHs with long-term migrant workers. In this context, push factors (financial) for mass migration become very expressive. This is due partly to the larger size of the HHs with an average of 6.3 members. On the other hand, remittancereceiving $\mathrm{HHs}$ with long-term migrant workers have the highest income per $\mathrm{HH}$ member (significantly higher than the other five categories). Turning to the expenditure side of $\mathrm{HH}$ budgets it is clear that access to remittances increases the purchasing power of remittancereceiving Nepali HHs, as well as increases their investment behavior. When looking at consumption patterns and day-to-day expenses (such as food, clothes, utilities), overall, remittance-receiving $\mathrm{HHs}$ spend a smaller percentage of their $\mathrm{HH}$ incomes on these costs. From the perspective of maximizing migrant worker remittances and savings on the development of Nepal, the most significant difference between remittance receiving and non-receiving $\mathrm{HHs}$ is that remittance-receiving $\mathrm{HHs}$ are much more likely to engage in investment and have business expenses, including farm expenses (animal feed, maintenance, etc.), as well as in savings. Overall, remittance-receiving HHs spend 60 per cent more on education, savings, investment or repaying debts than remittance non-receiving HHs. 
Patan Pragya (Volume: 7 Number: 1 2020)

Table 2: HH average monthly income in the past 12 months, by remittance receiving status and migration status (total income, share of income source, average size of $\mathrm{HH}$ and average income per $\mathrm{HH}$ member)

\begin{tabular}{|c|c|c|c|c|c|c|c|}
\hline S.N & HH budget Income & Recei & remitt & & $\begin{array}{l}\text { Do } \\
\text { remitta }\end{array}$ & $\begin{array}{l}\text { not } \\
\text { ices }\end{array}$ & receive \\
\hline 1 & $\begin{array}{l}\text { Rental income from property (land, } \\
\text { house, vehicle etc. }\end{array}$ & $1 \%$ & $1 \%$ & $3 \%$ & $4 \%$ & $5 \%$ & $5 \%$ \\
\hline 2 & $\begin{array}{l}\text { Borrowing money from others, credits } \\
\text { from banks }\end{array}$ & $12 \%$ & $8 \%$ & $19 \%$ & $16 \%$ & $28 \%$ & $14 \%$ \\
\hline 3 & Salary from private sector job & $7 \%$ & $3 \%$ & $23 \%$ & $5 \%$ & $7 \%$ & $16 \%$ \\
\hline 4 & Salary from public sector job & $2 \%$ & $2 \%$ & $9 \%$ & $2 \%$ & $5 \%$ & $11 \%$ \\
\hline 5 & $\begin{array}{l}\text { Salary from temporary/seasonal job } \\
\text { (agro based) }\end{array}$ & $5 \%$ & $1 \%$ & $2 \%$ & $9 \%$ & $5 \%$ & $3 \%$ \\
\hline 6 & $\begin{array}{l}\text { Salary from temporary/seasonal job } \\
\text { (non-agro based) }\end{array}$ & $11 \%$ & $3 \%$ & $6 \%$ & $24 \%$ & $5 \%$ & $9 \%$ \\
\hline 7 & $\begin{array}{l}\text { Pension/ other allowances (old age } \\
\text { allowance, disability allowance, etc) }\end{array}$ & $2 \%$ & $2 \%$ & $1 \%$ & $2 \%$ & $12 \%$ & $4 \%$ \\
\hline 8 & Other business income & $4 \%$ & $6 \%$ & $24 \%$ & $8 \%$ & $13 \%$ & $14 \%$ \\
\hline 9 & Sale of crops and livestock & $16 \%$ & $16 \%$ & $12 \%$ & $7 \%$ & $7 \%$ & $24 \%$ \\
\hline 10 & $\begin{array}{l}\text { Remittances (transfers from abroad both } \\
\text { through formal and informal channels) }\end{array}$ & $38 \%$ & $62 \%$ & $22 \%$ & $0 \%$ & $0 \%$ & $0 \%$ \\
\hline 11 & Other & $2 \%$ & $2 \%$ & $2 \%$ & $1 \%$ & $2 \%$ & $3 \%$ \\
\hline 12 & TOTAL & $\$ 146$ & $\$ 323$ & $\$ 371$ & $\$ 116$ & $\begin{array}{l}\$ \\
243\end{array}$ & $\$ 276$ \\
\hline 13 & Size of HH (average) & 6.3 & 4.832 & 4.1 & 6.3 & 5.4 & 5.2 \\
\hline 14 & $\begin{array}{l}\text { Number of children (up to } 15 \text { years) } \\
\text { (average) }\end{array}$ & 2.1 & 1.6 & 1.1 & 2.0 & 1.7 & 1.4 \\
\hline 15 & $\begin{array}{l}\text { Number of old people (65 years }+ \text { ) } \\
\text { (average) } \\
\text { Income per HH member (average) } \$ 23.2\end{array}$ & 0.3 & 0.2 & 0.2 & 0.2 & 0.4 & 0.3 \\
\hline
\end{tabular}

Sources: International Migration survey, 2017.

\section{Prevailing laws and policies}

According to The Foreign Employment Act, 2007, and the accompanying Rules (2008) govern all matters of migration for foreign employment from Nepal. The law and its Rules promote the security and welfare of foreign labour migrants, with provisions for the protection of their rights and for the regularization and monitoring of the businesses that 
facilitate the migration process. The provisions include creation of the Foreign Employment Welfare Fund, insurance coverage, pre-departure orientation and training, compensation to migrant workers and their families, rescue and repatriation of migrant workers and repatriation of workers' income. In addition, they specify the provision of monitoring mechanisms, such as a facility at the international airport, a mechanism to receive, investigate and adjudicate complaints as well as a tribunal to settle cases and penalize perpetrators. These provisions are implemented through various institutional mechanisms established with enactment of the Act: the Department of Foreign Employment, the Foreign Employment Promotion Board and the Foreign Employment Tribunal. Labour attachés are posted as appointees to Nepali embassies in the destination countries to facilitate the redress of labour migrants' grievances and distress (section 3.1.3 for more details on labour attachés). The Migrant Workers’ Welfare Fund was created under the Foreign Employment Promotion Board, and a Labour Desk was established at Kathmandu International Airport. Keeping pace with the expanding challenges and dynamics of foreign labour migration, necessary amendments to the 2008 Foreign Employment Rules were made in 2011, and the Act is now under review. When this development is completed, it is expected that labour migration will be safer, more decent and dignified.

\section{Conclusion:}

Nepal has a long history of emigration and it is in increasing trends. Now, however, migration to Gulf States and Malaysia has increased greatly, the participation of women in this emigration for work in foreign countries has been increasing too. Nepal has observed the largely growing phenomena of an absent population over the census periods. Whereas the 2001 census recorded that there was an absent population of 762,181, the 2011 census identified more than double that is 1,921,494 absent people, 7.3 percent of the total population. Unexpectedly, the foreign labor migration has developed in such a way, which has shifted the agricultural based economy towards remittance based economy in Nepal. As with the migration rate, the volume of remittances and their contribution to household economy has increased significantly in recent times. The share in Nepal's GDP stands as the third largest in the world.While on one hand, the country on the supply.

The Ministry of Labour and Employment realizes the slow implementation of the 2012 Foreign Employment Policy in the absence of strategic action plan in initial stage. The Ministry of Labour and Employment recently developed a five-year National Strategic Action Plan to carry out the Foreign Employment Policy. This plan along with a committed team should ensure that the policy is fully implemented. Based on past experiences, a policy of any type should be backed by the simultaneous formulation of an appropriate law and action plan to follow through in letter and spirit. The management of labour migration 
should be decentralized and thus accessible where migrants originate (in the far-flung districts) rather than solely functioning in Kathmandu. This would help reduce costs for would-be migrants. The Ministry of Labour and Employment, the Department of Foreign Employment and the Foreign Employment Promotion Board should consider provincialbased offices to assist workers wanting to migrate abroad for employment. There is need for incentive packages, which the Ministry of Finance and the banking sector should develop, to motivate Nepali workers abroad to use the formal remittance channel to capture a larger volume of remittances while ensuring security and reliability of their money transfers.The formal banking system is largely not available in rural areas. There is a need to assess the feasibility of innovative services, including mobile technology and other forms of digital technology, so that households receive remittances faster, more cheaply and in their vicinity in a more secured way. There is an urgency to extend social security coverage to children and senior citizens who are devoid of care.With development finance comprising official development assistance, foreign direct investment, debt and remittances, which make the largest contribution, remittances should be central to the development discourse. The Ministry of Labour and Employment should be represented in international forums on development finance. The 2015 earthquake disaster has created a huge task of reconstruction, yet there is a lack of human resources for what is needed. A wage policy should be devised to pay youths what they could earn by going abroad to stem the outflow of workers. This will also stop the outward cash flow that results from the hiring of foreign workers from neighboring countries. The reconstruction phase can also target the skills of returned migrant workers.

In this article examines migration and development links that are largely unexplored by the Nepali government (national and local), analysts, commercial financial intermediaries, and other stakeholders in the private and civil sectors. By closely examining possible means of promoting positive aspects of circular migration, and in particular its relation to the link between development and migration-related financial flows, this study intended to go beyond the standard remittance discussion. The financial, human and social capital accumulated by migrant workers abroad are interlinked their accumulated wealth has real potential to substantially impact the economic and social development of Nepal.

\section{References}

Central Bureau of Statistics (CBS), (2011). National Population and Housing Census 2011 (Kathmandu, Central Bureau of Statistics, Government of Nepal), pp. 211-237. 
International Labour Organization, (2015). Labour market trends analysis and labour migration from South Asia to Gulf Cooperation Council Countries, India and Malaysia (Kathmandu, ILO).

International Labour Organization, (2015).InternationalMigration Report 2017: Highlights(ST/ESA/SER.A/404).

IDMC (2019).Global Report on Internal Displacement. Available at www.internaldisplacement.org/sites/

Ministry of Labour and Employment, (2015).Labour migration for employment: A status report for Nepal, 2014/2015 (Kathmandu).

Pradhan, A. et al.(2011). A review of the evidence: Suicide among women in Nepal (Kathmandu, Ministry of Health and Population, Government of Nepal).

Sijapati, B.; Limbu, A. (2012). Governinglabour migration in Nepal: An analysis of existing policies and Institutional Mechanisms (Kathmandu, Centre for the Study of Labour and Mobility)

United Nations. (2014). The least developed countries report 2014: Growth with structural transformation: A post-2015 development agenda (Geneva, United Nations Conference on Trade and Development Secretariat).

United Nation (UN). (2017). International Migration Report 2017: Highlights. New York: United Nations.

World Bank, (2011). Large scale migration and remittance in Nepal: Issues, Challenges and Opportunities (Kathmandu, The World Bank).

World Bank (WB). (2019). Migration and remittances, recent development and outlook. Migration and development brief 28. Retrieved from https://www.worldbank.org/en/topic/labormarkets/brief/migration-and-remittances.

United Nations, Department of Economic and Social Affairs, Population Division (2017). default/files/publications/documents/2019-IDMC-GRID.pdf. 